\title{
Correction to: Probiotic potential of lactic acid bacteria obtained from fermented curly kale juice
}

\author{
Julia Szutowska ${ }^{1}\left[\right.$ [ Daniela Gwiazdowska ${ }^{1}$ (1)
}

(c) The Author(s) 2021

\section{Correction to: Archives of Microbiology (2021) 203:975-988 https://doi.org/10.1007/s00203-020-02095-4}

In the original article, the legend for Fig. 3 is missing. The missing information is given as follows.

Figure $3 \mathrm{NaCl}$, acid and bile salt tolerance. a $L$. mesenteroides JS001, b Leuconostoc spp. JS017, c L. mesenteroides JS024, d L. mesenteroides JS027, e Leuconostoc spp. JS031, f $L$. sakei $\mathrm{JS} 032, \mathbf{g}$ L. plantarum $\mathrm{JS} 034, \mathbf{h}$ L. plantarum JS052, i L. plantarum JS053, $\mathbf{j} L$. coryniformis JS058, $\mathbf{k} L$. coryniformis JS070, I L. coryniformis JS075
Open Access This article is licensed under a Creative Commons Attribution 4.0 International License, which permits use, sharing, adaptation, distribution and reproduction in any medium or format, as long as you give appropriate credit to the original author(s) and the source, provide a link to the Creative Commons licence, and indicate if changes were made. The images or other third party material in this article are included in the article's Creative Commons licence, unless indicated otherwise in a credit line to the material. If material is not included in the article's Creative Commons licence and your intended use is not permitted by statutory regulation or exceeds the permitted use, you will need to obtain permission directly from the copyright holder. To view a copy of this licence, visit http://creativecommons.org/licenses/by/4.0/.

The original article can be found online at https://doi.org/10.1007/ s00203-020-02095-4.

Julia Szutowska

julia.szutowska@ue.poznan.pl

1 Department of Natural Science and Quality Assurance, Institute of Quality Science, Poznań University of Economics and Business, Poznań, Poland 